\title{
Christian-Based Positive Discipline Program in Enchanged Mindful Parenting Skills of Mothers
}

\author{
Tiurma Basa Marina Simanjuntak ${ }^{1 *}$, Tina Hayati Dahlan², Mubiar Agustin ${ }^{3}$
}

\author{
${ }^{1}$ Student of Educational Psychology Post Graduate Program of Universitas Pendidikan Indonesia \\ ${ }^{2}$ Lecturer of Educational Psychology Post Graduate Program of Universitas Pendidikan Indonesia \\ ${ }^{3}$ Lecturer of Early Childhood Education of Universitas Pendidikan Indonesia \\ Corresponding Email: tiurmabasamarina@gmail.com
}

\begin{abstract}
Parenting is one of the most challenging and stressful jobs. At the same time, its significance lies in the influence it has on the life of the one being parented. Mothers of preschool had difficulties on emotion control, automatic reaction, receive herself and child, and take care themself. These reactions emerge because lack of the mindful parenting skills. Mindful parenting skills are the ability of mother in parenting that involve self-awareness, attention without judgment and the present situation-oriented. Mindful parenting skill could enhance by Christian based-positive discipline program. This program was aims to improving parenting skill that consists of listening with full attention, nonjudgemental acceptance of self and child, emotional awareness of self and child, self-regulation in the parenting relationship and compassion from self and child. This program was held 5 times, with time duration about 120 minutes respectively, and using methods such as lecture, focus group discusion, role play, reflection, discussion, case study and mindful breathing. Searching for mindful parenting skills was carried out 2 times design of exeperimental study withh pretest and posttest. The result analysis showed homogenus data $(f=4,22 ; p>0,05)$, improving higer mindful.
\end{abstract}

Keywords: Christianity, early childhood, mindful parenting, mother, positive discipline

\section{INTRODUCTION}

Mothers with preschoolers have the task of creating a safe and comfortable environment for children, also providing opportunities for children to freely explore the environment, satisfy their curiosity and try new things for them (Bluth K., 2011). Preschoolers children need for autonomy that result opposition behavior and frustration that would trigger anger and pressure for parents (Corthorn, 2018). Children start asked many questions, want to play, to explore the environment, develop creativity, cognitive, physical and motoric development that determines the formation of children's behavior and personality in the future.

Preschoolers children tend to create problems and conflicts for mothers, which causing stress for caring that hinders parents' activities as well as the child's growth. Mothers who are unable to cope with stress will either remain silent or vent with emotion. Parents especially mothers have to able to overcome the conditions and rise to do the best for their children (Davis, N. O., \& Carter, 2008).
Mindful parenting is considered to be essential for Effective parenting because this implies that the parent is trully present in the moment-moment parentchild interactions and is therefore more able to emotionally connect with her child and respond to his or her needs (Duncan, L. G., Coatsworth, J. D., and Greenberg, 2009). Research on aspects of openness, ability to relate, communicate feelings, emotional regulation, anger management have a positive impact on parenting and better parental relationships among children (Kabat-Zinn, M., and Kabat-Zinn, 1997; Dumas, 2005; Brown, K. W., Ryan, R. M., and Creswell, 2007)

The reaction of the mother who has difficulty regulating the child would response by speaking in a loud volume, pinching the child and lack of emotional control are an autopilot reaction from parents in responding to the child's behavior. Parents, especially mothers, automatically or unconsciously repeat the pattern of dysfunctional parenting that they recognize since childhood (Belsky, J., Conger, R., \& Capaldi, 2009). Mothers have a 'childcare scheme' which consists of information and experiences they have 
learned as children, when cared for by their own parents (Bogels,S. M., Lehtonen, A., and Restifo, 2010).

Mothers are assumed automatically or unconsciously, repeating the dysfunctional parenting patterns they have identified since childhood, so that transmission of cognitive parenting occurs in generations according to the childcare scheme that has been learned from their experiences (Young, 1994; Bogels,S. M., Lehtonen, A., and Restifo, 2010). This automatic reaction is known as the autopilot reaction, which saves limited attention resources and reduces limited self-regulation of unnecessary tasks (Bargh, J. A., \& Chartrand, 1999; Kang, Y., Gruber, J., Gray, 2013).

Christian parenting based on love as God gives unconditional love to man (Tanusaputra, 2005). Parents especially mothers will tell and teach their children with compassion about spiritual truth, faith and love, responsibility to God and put hope in God. Parenting is an effort given by God that requires personal sacrifice and is a top priority for parents in caring for children (Volling, B.L., Mahoney, A., Amy, 2009). Christian parenting aims to helping children to love God and guiding them to fulfill His calling, that is to be a useful for others.

Christian parenting (Cartier, 1978) reflects the seven dimensions of God's love conclude caring, responsiveness, disciplined, giving, respecting, recognizing and forgiving. These seven principles are a image of God's love for man that should be emulated by parents when parneting their children, making it a characteristic of Christian parenting in the family.

Mindful parenting is a parent's awareness in giving attention, aiming and not giving a label or negative value for every child's experience (Duncan, L. G., Coatsworth, J. D., and Greenberg, 2009). Parents who practice mindful parenting in their interactions with children, will be more calm in facing negative children's behavior (Bogels,S. M., Lehtonen, A., and Restifo, 2010), more consistent, and have clear goals and values in parenting (Duncan, L. G., Coatsworth, J. D., and Greenberg, 2009). The concept of mindful parenting enhances positive interactions between parents and children, for example, increasing positive feelings and reducing negative feelings, increasing parental trust, and increasing the ability to share feelings (Duncan, L. G., Coatsworth, J. D., and Greenberg, 2009; Singh, N.N., Singh, A.N., Lancioni, 2009; Coatsworth, 2015).

The mother is the closest figure to the child. Since pregnancy and breastfeeding, the bonding between mother and child begins. Interactions that occur are not always happy, sometimes mothers experience conflicts to stress in dealing with children.
This condition is called parenting stress. Parenting stress is the stress experienced by parents in the parenting process that involves an array of coping skill for behavior and communicating with children, caring, nurturing, finding a way to overcome problems, and their effects on personal and family life (Dabrowska, A., Pisula, 2010). Mothers need training to improve their mindful parenting skills so they can deal with childcare issues.

Mindful parenting makes parents, especially mothers, more attentive, more aware about effect of the respons to their interactions with children and learn to be more deliberate in caring for their children to choose ways that enhance and maintain positive emotional relationships. Mothers who have positive emotions usually have the ability to actualize themselves, have a purpose in life, and self-acceptance. Parents will transmit positive feelings when caring for children (Singh, N.N, Lancio, G.E, Winton, 2010).

Mindful parenting skills are needed in parenting in preschoolers children or the golden ages because they determine the formation of character, namely attitudes, behavior and personality of children in the future (Dorlina N., 2011). The role of care is very important in helping children through the creation of stimuli in the environment that can optimize all aspects of child development, by training, explaining, correcting or showing something to children, so that children become well experienced (Mönks, F.J, Knoers, A.M.P \& Haditono, 2004; Woolfolk, 2006)

Children will learn well if they get the support and various information they need in life from adults around them, especially parents. Positive discipline has the basic assumption that children are born without knowing the expectations of parents towards them, so that children learn from attitudes and situations that occur in the environment, especially the family. Positive support from parents and information provided by parents in an effort to structure children's expectations so that they can be understood by children.

A positive attitude in parenting is the main foundation for children to place themselves, a sense of security and comfort in providing learning experiences about positive values in life. A positive attitude can be shown unconditionally compassionate parents who are verbally or physically, respectful, sensitive to the needs of children, listening, accepting children without judgment, self-regulation and emotional awareness. This positive attitude enhances mindful parenting skills, so parents consider something before doing an action.

A positive discipline strategy is one of the approaches that has begun to be widely used to improve self-control, responsibility and assist children in 
making wise choices (Somayeh, G., SayyedMirsah, J., SayyedMostafa, S., Azizollah, 2013). This strategy prioritizes long-term goals more than just overcoming behaviors that appear at the moment, done with the warmth of the mother, prioritizing the needs and affections of children to overcome problems (Durrant, 2016). A Christian-based positive discipline strategy is a development of positive discipline in everyday parenting (Durrant, 2016) an intervention prepared by researchers aimed at increasing the mother's mindful parenting skills.

Christian-based positive discipline strategies encourage appropriate children's behavior, so the less time and effort they spend to correct bad behavior. This strategy is carried out by giving positive attention on a regular basis which sometimes requires special time; listen carefully to children and help them learn to use words to express their feelings; giving children the opportunity to make choices whenever appropriate choices exist and then helping them learn to evaluate the potential consequences of their choices; strengthen desired behavior; and modeling rules, predictable behavior, respectful communication, and collaborative conflict resolution strategies (Flaskerud, 2011). This discipline strategy is needed to reduce or eliminate behaviors that are not wanted by parents.

This strategy is based on the goal of Christian parenting which is based on love (Vitaurus, 2015). Mothers take care of their children based on the 7 dimensions of God's love that describe God's love for His people (Cartier, 1978), namely caring, responsiveness, disciplined, giving, respecting, recognizing and forgiving. These seven principles are a picture of God's love for man that should be emulated by parents in caring for children, making it a characteristic of Christian obedience in the family. Practicing Christian based positive discipline can improve mindful parenting skills of mothers.

\section{METHOD}

\subsection{Participant}

This research is a quasi-experimental with nonequivalent control group pretest and post test. Participants totaling 20 people are mothers of the Christian community who have children aged 4 to 6 years, with a minimum of high school education. Sampling with a purposive sampling technique, consisting of 10 mothers in the Christian community in Bandung in the experimental group and 10 control groups.

\subsection{Measures}

The measurement of mindful parenting skills is done using the Mindful Parenting Scale developed by Tiurma, et al from IM-P (Duncan, L. G., Coatsworth, J. D., and Greenberg, 2009) containing 15 items which are a 5-dimensional description of listening to children attentively, acceptance without judgment of self and child, emotional self-awareness and children, selfregulation and self-compassion. The 15 items are rated on a 10-point Likert scale ranging from 1 as the lowest and 10 as the higest. This scale has been tested on 75 mothers with children aged 4 to 6 years with 13 valid items, 2 items were revised with a reliability of 0.95 . Mindful Parenting Scale measurements were carried out 2 times, namely before the program and after the program for both the experimental and control groups. Additional data were obtained from interviews and journals which contained parenting activities, successes and obstacles in accordance with the theme of the weekly session and the recording of the program's ongoing process.

The program is structured for 5 meetings, namely once a week with a duration of \pm 120 minutes. The program has been carried out by expert judgment before it is given to mothers. Methods of learning such as lecture, focus group discussion, role play, reflection, discussion, case study and mindful breathing. Each session has an indicator of success in accordance with the theme of the session. The program is considered successful if the mother meets these criteria.

\section{RESULT}

The results of the maternal Mindful Parenting Skill Scale measurement in the pre-test and post-test for the control group showed $\mathrm{M}=0.0429$ with $\mathrm{SD}=0.35$ and the experimental group $\mathrm{M}=0.37$ and $\mathrm{SD}=0.19$. The experimental group had $\mathbf{M}=0.37$ which was higher than the control group $\mathrm{M}=0.042$. The analysis showed that homogeneous data ( $f=4.22 ; p>0.05$ ), there were differences in mindful parenting skills, where the experimental group was higher than the control group $(t=-2,619, p<0.01)$, influenced by the participation in a positive Christian discipline-based strategy program.

\section{DISCUSSION}

The Christian-based positive discipline strategy program is structured to improve mindful parenting skills characterized by Christian parenting grounds. This program consists of 5 meetings, namely: 1). Set a 
parenting goal based on the Bible; 2). Creating warmth and structure based on the 7 dimensions of God's love; 3 ). Knowing the thoughts and feelings of children preceded by self-recognition; 4). Alternative problem solving; 5) review and evaluation. Every material and activity in the session is arranged to be arranged to improve the mindful parenting skills of the mother, namely listening attentively; non-judgmental acceptance of self and child; emotional and child emotional awareness; attentive listening arrangements; and self and child compassion (Duncan, L. G., Coatsworth, J. D., and Greenberg, 2009)

The results obtained from this study indicate that the Christian-based positive discipline Strategy Program is influential in improving mindful parenting skills. Based on quantitative analysis it was found that there were significant differences in the scores of mindful parenting skills where the mean experimental group was higher than the control group. This result is also supported by qualitative data which shows that in general participants who participated in this program reported changes that were felt after attending training, including increasing knowledge about the task of preschool age development tasks, learning to control emotions, not reacting quickly to children and getting to know self and child making it easier for mothers to care for children.

The success of this program adds to the training model that can improve mindful parenting skills, programs that have been successful before. (Mubarok, 2016) suggested an effective positive parenting program in enhancing the mindful parenting skills of teenagers, (Coatsworth, 2015) integrating mindfulness training into a family strengthening program, which effectively enhances several dimensions of caregiving, including attention, the quality of children's parent relationships, management of child behavior and parental welfare.

The success of this program is influenced by training modules, facilitators and participants (Johnson, C. A., \& Johnson, 2001). This module was compiled by researchers through a review of relevant research concepts and results, as well as professional judgment. Material delivery techniques are done with variations, namely presentation, FGD, games, analysis of short films and assignments in the form of entries as well as journals that must be done by the participants during the program. Participants get an understanding of the experience or activities carried out.

The mother was enthusiastic in participating in the program, as seen from the questions asked and the way they discussed a problem, all were actively involved in giving their opinions. The atmosphere of intervention is conducive for mothers to receive knowledge to improve their mindful parenting skills.

The success of this program was analyzed quantitatively and qualitatively. The results of the qualitative analysis of participants experienced an increase in the dimensions of minduful parenting. Mothers report an increase in the dimensions of listening to children attentively, acceptance without judgment of themselves and children; emotional and child emotional awareness; attentive listening arrangements; and self and child compassion. Mothers are more able to hold emotions, delay talking to children when they are upset, stop from activities and listen to children tell stories, stop from routine activities and try to do activities that can please themselves. Mothers who calmly respond to children (Bogels,S. M., Lehtonen, A., and Restifo, 2010) make children calmer in their attitude. Mothers transfer positive feelings to children (Singh, N.N, Lancio, G.E, Winton, 2010)

Making Bible-based parenting goals gives mothers insight into Christian parenting based on love. Love becomes the foundation for parents to take care of their children, guiding them in knowing God and helping children to fulfill His call to be a blessing to others. Mothers who experience increased mindful parenting skills set an example for children to respond to events.

This intervention is also a technique of being aware of bodily sensations (Selby, 2004) by using mindful breathing. The technique of being aware of bodily sensations including breathing awareness helps participants to release emotional barriers, especially negative emotions that affect the physical and be aware of experiences and bring them to their present condition. The state of consciousness helps the individual escape from the past and future worries. This helps manage negative thoughts and reduce self-blame.

Nine participants reported being able to enjoy the technique of being aware of body sensations while in class, only one participant had difficulty enjoying relaxation (feeling bodily sensations). But they said they forgot to do mindful breathing in the caregiving situation at home. Other participants report when emotions cannot enjoy relaxation. Participants who did it in the morning after praying felt calmer in caring for children.

Limitations of research in terms of participants, among others, busy mothers in carrying out tasks such as mother and wife make some participants slow in doing the journal, not every day the journal is filled. Researchers provide an alternative for mothers who cannot write, can be recorded on a cellphone then write it. Mother cannot come to the program when the child is sick. Childrens in one school were affected by 
infuenza, affected mothers not come. The researcher sends the following program record with assignments. Mother gived a special explanation because they have not understand.

\section{CONCLUSION}

The positive strategy program for Christian free disciplines for 5 weeks with a duration of 120 minutes for each migraine is effective in increasing the mother's mindful parenting skills. This intervention improves the mother's skill in listening attentively; nonjudgmental acceptance of self and child; emotional and child emotional awareness; attentive listening arrangements; and self and child compassion (Duncan, L. G., Coatsworth, J. D., and Greenberg, 2009)

\section{REFERENCES}

[1] Bargh, J. A., \& Chartrand, T. L. (1999) 'The Unbearable Automaticity of Being', American Psychologist, 54, pp. 462-479.

[2] Belsky, J., Conger, R., \& Capaldi, M. (2009) 'The Intergenerational Transmission of Parenting: Introduction to the Special Section', Developmental Psychology, 24, pp. 1201-1204.

[3] Bluth K., W. R. (2011) 'Parentng Presschoolers: Can Mindfulness Help?', Springer Science Business Media, LLC 2011. doi: 10.1007/s112671-011-0071-4.

[4] Bogels,S. M., Lehtonen, A., and Restifo, K. (2010) 'No Title', Journal of Mindfulness, 1, pp. 107-120.

[5] Brown, K. W., Ryan, R. M., and Creswell, J. D. (2007) 'Mindfulness: theoretical foundations and evidence for its salutary effects', Psychol. Inq, 18, pp. 1-26. doi: 10.1080/10478400701598298.

[6] Cartier, M. (1978) 'Parenting: A theological model', Sagepub journal. doi: $10.1177 / 009164717800600108$.

[7] Coatsworth, J. D. (2015) 'Integrating mindfulness with parent training: Effects of the mindfulnessenhanced strengthening families program', Developmental Psychology, 51(1), pp. 26-35.

[8] Corthorn, C. (2018) 'Benefits of mindfulness for parenting in mothers of Preschoolers in Chile', Frontiers of Psychology, 9, p. 1443. doi: 10.3389/fpsyg. 2018.01443.

[9] Dabrowska, A., Pisula, E. (2010) 'Parenting stress and coping styles in mothers and fathers of preschool children with autism and Down syndrome', Journal of Intellectual Disability Research, 54(3), pp. 266-280. doi: 10.1111/j.1365-2788.2010.01258.x.

[10] Davis, N. O., \& Carter, A. S. (2008) 'Parenting stress in mothers and fathers of toddlers with autism spectrum disorders: Associations with child characteristics', Journal of Autism \& Developmental Disorders, 38, pp. 1278-1291.

[11] Dorlina N. (2011) 'Perkembangan Bahasa Anak Prasekolah', Jurnal Pembina Pengembangan Pendidikan, 8(1).

[12] Dumas, J. E. (2005) 'Mindfulness-based parent training: strategies to lessen the grip of automaticity in families with disruptive children', J. Clin. Child Adolesc. Psychol, 34, pp. 779-791. doi: 10.1207/s15374424jccp3404_20.

[13] Duncan, L. G., Coatsworth, J. D., and Greenberg, M. T. (2009) 'A model of mindful parenting: implications for parent-child relationships and prevention research', Journal of Clinical Children Family Psychology, 12, pp. 255-270.

[14] Durrant, J. E. (2016) Positive Discipline in Everyday Parenting. Stockholm: Save the children Sweden.

[15] Flaskerud, H. J. (2011) 'Discipline and Effective Parenting', Mental Health Nursing, 32, pp. 82-84

[16] Johnson, C. A., \& Johnson, F. P. (2001) Joining Together: Group Theory and Group Skills. Boston: Allyn \& Bacon.

[17] Kabat-Zinn, M., and Kabat-Zinn, J. (1997) Everyday Blessings: The Inner Work of Mindful Parenting. NewYork: NY:Hyperion.

[18] Kang, Y., Gruber, J., Gray, J. R. (2013) 'Mindfulness and de-automatization', Emotion Review, 5(2), pp. 192-201. doi: $10.1177 / 1754073912451629$.

[19] Mönks, F.J, Knoers, A.M.P \& Haditono, S. R. (2004) Psikologi Perkembangan Pengantar dalam Berbagai Bagiannya. Yogyakarta: Gadjah Mada University Press.

[20] Mubarok, P. (2016) 'Program pengasuhan positif untuk meningkatkan keterampilan mindful parenting orangtua remaja', Psympathic, Jurnal Ilmiah Psikologi, 3(1), pp. 35-50.

[21] Selby, J. (2004) Meditation the cool way to calm. Boston: Tuttle Publishing.

[22] Singh, N.N, Lancio, G.E, Winton, A. S. W. (2010) 'Training in mindful caregiving transfer to parent child interaction', Journal of Child Family Study, 19, pp. 167-174

[23] Singh, N.N., Singh, A.N., Lancioni, G. E. (2009) 'Mindfulness training for parents and their children with ADHD increases the children's compliance', Journal of Child Family Study, 19, pp. 157-166.

[24] Somayeh, G., SayyedMirsah, J., SayyedMostafa, 
S., Azizollah, A. (2013) 'Investigating the effect of positive discipline on the learning process and its achieving strategies with focusing on the students' abilities', International Journal of Academic Research in Business and Social Sciences, 3(5).

[25] Tanusaputra, D. (2005) 'Teologi pernikahan dan keluarga', Veritas $6 / 1$, pp. 73-101.

[26] Vitaurus, H. (2015) 'Peran orang tua dalam menerapkan kasih dan disiplin kepada anak usia 2-6 tahun sebagai upaya pembentukkan karakter', Jurnal Teologi dan Pendidikan Agama Kristen, 3(1), pp. 48-65. Available at: http://www.sttpb.ac.id/ejournal/index.php/kurios.

[27] Volling, B.L., Mahoney, A., Amy, J. (2009) 'Sanctification of Parenting, Moral Socialization, and Young Children's Conscience Development', Psycholog Relig Spiritual, 1(1), pp. 53-68. doi: 10.1037/a0014958.

[28] Woolfolk, A. (2006) Educational psychology. Boston: Pearson Education. Inc.

[29] Young, J. E. (1994) Cognitive therapy for personality disorders: A schema-focussed approach. Sarasota: FL: Professional Resource Press. 